\title{
Hyperhidrosis: causes and treatment options
}

\author{
Nadmierna potliwość - przyczyny i możliwości terapeutyczne
}

Olga Jabłonowska, Anna Woźniacka, Bożena Dziankowska-Bartkowiak

Department of Dermatology and Venereology, Medical University of Lodz, Poland

Klinika Dermatologii i Wenerologii, Uniwersytet Medyczny w Łodzi, Polska

Dermatol Rev/Przegl Dermatol 2020, 107, 246-256

DOI: https://doi.org/l0.5 I /4/dr.2020.97776

\author{
CORRESPONDING AUTHOR/ \\ ADRES DO KORESPONDENCJI: \\ lek. Olga Jabłonowska \\ Klinika Dermatologii \\ i Wenerologii \\ Uniwersytet Medyczny w Łodzi \\ Uniwersytecki Szpital Kliniczny \\ im. WAM \\ Plac Hallera 1 \\ 90-643 Łódź
}

e-mail: olga.jablonowska@gmail.com

\begin{abstract}
Excessive sweating (hyperhidrosis) is a common condition developing regardless of age, sex, and race, which often leads to a decrease in the quality of life. Depending on the cause, hyperhidrosis can be divided into the primary and secondary type (triggered by comorbidities, drugs, stress). Based on the degree of body involvement, hyperhidrosis may be either focal or generalised. Primary hyperhidrosis limited to certain body areas accounts for a vast majority of cases. According to the Canadian Hyperhidrosis Advisory Committee primary hyperhidrosis can be diagnosed if the symptoms persist for at least 6 months, and at least 4 of the following 6 criteria are fulfilled: bilaterally symmetric sweating, impairment of daily activities, more than 1 episode per week, age at onset $<25$ years, positive family history, and absence of symptoms during sleep. First-line therapy of primary hyperhidrosis is based on topical medications. If no improvement is noted, systemic or surgical options are considered (e.g. iontophoresis, botulin toxin injections). In secondary hyperhidrosis, the focus is on the treatment of the underlying cause.
\end{abstract}

\section{STRESZCZENIE}

Nadmierna potliwość jest chorobą, która występuje u osób wszystkich ras, płci, w różnym wieku i wielokrotnie jest przyczyną obniżenia jakości życia. Uwzględniając przyczynę, hiperhydrozę dzieli się na pierwotną oraz wtórną (wywołaną przez choroby współistniejące, leki, stres). Ze względu na zajmowany obszar ciała wyróżnia się hiperhydrozę uogólnioną oraz ograniczoną. W większości przypadków hiperhydroza ma charakter pierwotny i jest ograniczona do pewnych obszarów ciała. Według Canadian Hyperhidrosis Advisory Committee, aby rozpoznać hiperhydrozę pierwotną, należy potwierdzić utrzymywanie się objawów przez co najmniej 6 miesięcy oraz stwierdzić cztery z sześciu wymienionych kryteriów: występowanie obustronne i symetryczne, wpływ na codzienną aktywność, więcej niż 1 epizod w tygodniu, początek przed 25. rokiem życia, dodatni wywiad rodzinny, brak objawów podczas snu. Terapię hiperhydrozy pierwotnej rozpoczyna się od zastosowania preparatów miejscowych, a w przypadku ich nieskuteczności włączane jest leczenie ogólne, zabiegowe (np. jontoforeza, iniekcje toksyny botulinowej) oraz metody chirurgiczne. W terapii hiperhydrozy wtórnej nadrzędne jest leczenie przyczynowe. 
Key words: hyperhidrosis, primary hyperhidrosis, secondary hyperhidrosis, excessive sweating.

Słowa kluczowe: hiperhydroza, hiperhydroza pierwotna, hiperhydroza wtórna, nadmierna potliwość.

\section{INTRODUCTION}

Sweat glands play an important role in the body's thermoregulation and have direct links to the autonomic nervous system. At rest, sweat is constantly secreted by the body in small amounts, but its production increases in response to thermal or emotional stimuli [1]. The human body has 4 million sweat glands, of which about $75 \%$ are eccrine glands, and the remainder are apocrine glands. In primary hyperhidrosis, the main role is ascribed to an increased activity of eccrine glands.

Eccrine sweat glands are found all over the body, but occur in the highest density on the hands, forehead, soles of the feet, and in the axilla. The function of the eccrine glands is linked to the cholinergic system. The secretory activity is stimulated by thermal, emotional and gustatory stimuli. The main function of the glands is the body's thermoregulation. The eccrine sweat is an odourless hypotonic solution containing sodium, potassium, chlorides, urea, uric acid, lactates, biogenic amines, trace amounts of amino acids, and vitamins [2]. Higher concentrations of uraemic toxins in sweat have been reported in patients on dialysis due to renal failure [3]. Sweat is also a vehicle for the excretion of toxins including ethyl alcohol, phenazone, benzoic acid, salicylic acid, lead, mercury, and iron [4].

The apocrine sweat glands develop with the hair germs in the fourth to fifth months of foetal life, however, they grow and become active at puberty. In adults, apocrine glands are located mainly in the axillary, genital, and anal regions, around the navel, on the nipples, and occasionally also on the torso and head. Apocrine sweat gland innervation is believed to be adrenergic. The apocrine sweat is initially odourless, pale in colour, cloudy, and viscous. It contains cholesterol, triglycerides, and fatty acids. The characteristic odour developing after secretion is due to the decomposition of constituents of sweat by the bacterial flora on the skin [2].

Excessive sweating, exceeding the body's physiological needs, is referred to as hyperhidrosis. The condition affects both men and women of various age [5]. A recent study in the United States has shown that as many as $17 \%$ of adolescents report a problem

\section{WPROWADZENIE}

Gruczoły potowe odgrywają ważną rolę w termoregulacji organizmu i mają ścisły związek z autonomicznym układem nerwowym. W stanie spoczynku pot wydzielany jest stale w niewielkich ilościach, jednak w wyniku zadziałania bodźca termicznego lub emocjonalnego jego produkcja się nasila [1]. Organizm człowieka ma 4 miliony gruczołów potowych, z czego ok. 75\% stanowią gruczoły ekrynowe, natomiast pozostałe to gruczoły apokrynowe. W hiperhydrozie pierwotnej główną funkcję pełni wzmożona aktywność gruczołów ekrynowych.

Gruczoły ekrynowe występują na powierzchni całej skóry, w największej ilości na dłoniach, czole, podeszwach stóp oraz w dołach pachowych. Czynność gruczołów ekrynowych zależy od układu cholinergicznego. Aktywność części wydzielniczej pobudzana jest przez bodźce termiczne, emocjonalne i smakowe. Główną funkcję gruczołów stanowi termoregulacja organizmu. Pot ekrynowy jest bezwonnym, hipotonicznym roztworem zawierającym sód, potas, chlorki, mocznik, kwas moczowy, mleczany, aminy biogenne, śladowe ilości aminokwasów i witaminy [2]. U osób dializowanych z powodu niewydolności nerek występuje wyższe stężenie toksyn mocznicowych $\mathrm{w}$ pocie [3]. Wraz z potem wydalane są również toksyny, takie jak alkohol etylowy, fenazon, kwas benzoesowy, kwas salicylowy, ołów, rtęć i żelazo [4].

Gruczoły apokrynowe rozwijają się wraz z zawiązkami włosów między czwartym a piątym miesiącem życia płodowego, jednak dopiero w okresie dojrzewania powiększają się i uczynniają. U dorosłego człowieka zlokalizowane są głównie w okolicy pachowej, genitalnej, odbytu, wokół pepka, na brodawkach sutkowych, a także sporadycznie na tułowiu i głowie. Ich unerwienie jest adrenergiczne. Pot apokrynowy jest pierwotnie bezwonny, jasny, mętny, lepki, zawiera cholesterol, triglicerydy oraz kwasy tłuszczowe. Charakterystyczny zapach powstający po jego wydzieleniu wynika z rozkładu produktów przemiany zachodzącej pod wpływem skórnej flory bakteryjnej [2].

Nadmierna, przekraczająca fizjologiczne potrzeby organizmu produkcja potu określana jest terminem hiperhydrozy. Dotyczy zarówno kobiet, jak i mężczyzn w różnym wieku [5]. Ostatnio przeprowadzo- 
with excessive production of sweat [6]. Hyperhidrosis has been classified into two variants: primary and secondary.

\section{VARIANTS}

\section{Primary hyperhidrosis}

An analysis of the causes of hyperhidrosis has found that it is primary in origin in $90 \%$ of cases [7]. Other cases are considered to be secondary hyperhidrosis. The aetiopathology is believed to involve genetic, emotional and environmental causes. According to the Canadian Hyperhidrosis Advisory Committee primary hyperhidrosis can be diagnosed if the symptoms persist for at least 6 months, and at least 4 of the following 6 criteria are fulfilled: bilaterally symmetric sweating, impairment of daily activities, more than 1 episode per week, age at onset $<25$ years, positive family history, absence of symptoms during sleep [8] (table 1).

In the majority of cases, primary hyperhidrosis is limited to a specific location on the skin. It mainly affects the hands, feet, armpits and face, and it is typically located in several anatomical areas concurrently [9]. The prevalence of primary hyperhidrosis varies depending on the region of the world. Based on studies conducted in the United States, primary hyperhidrosis occurs with a prevalence of $2.8-4.8 \%$, while the prevalence rate in Sweden is 5.5\%, in Germany $4.6 \%$, in Japan $12.8 \%$, in Canada (Vancouver) $12.3 \%$, and in China (Shanghai) $14.5 \%$ of the population [10-14].

\section{Secondary hyperhidrosis}

Secondary hyperhidrosis is caused by comorbidities or medications taken by the patient. It may accompany, among others, such conditions as hyperthyroidism, diabetes mellitus, obesity, tuberculosis, endocarditis, Parkinson's disease, pheochromocytomas, and Hodgkin's lymphomas. Other reported causes of hyperhidrosis include drugs, for example, neuroleptics, antidepressants, hypoglycaemics, triptans, opioids, antibiotics (ciprofloxacin), antivirals (acyclovir), antiemetics, antipyretics, non-steroid anti-inflammatory drugs, and drugs with adrenergic and cholinergic actions [7]. Physiologically normal secondary hyperhidrosis often occurs during pregnancy and menopause, and in response to exposure to high temperatures. In this type of hyperhidrosis, excessive sweating is typically generalised, involving the whole body [5].

Hyperhidrosis may also accompany rare medical conditions such as Frey's syndrome, Riley-Day syndrome, and nail-patella syndrome [15-17]. ne badanie w Stanach Zjednoczonych wykazało, że aż $17 \%$ nastolatków zgłasza problem nadmiernego wydzielania potu [6]. Wyróżniono dwie postacie hiperhydrozy: pierwotną i wtórną.

\section{POSTACIE}

\section{Hiperhydroza pierwotna}

Analizując przyczyny hiperhydrozy, stwierdzono, że w 90\% ma ona charakter pierwotny [7]. Pozostałe przypadki uznaje się za nadpotliwość wtórną. W etiopatologii postaci pierwotnej upatruje się przyczyn genetycznych, emocjonalnych oraz środowiskowych. Według Canadian Hyperhidrosis Advisory Committee, aby rozpoznać hiperhydrozę pierwotną, należy potwierdzić utrzymywanie się objawów przez co najmniej 6 miesięcy oraz stwierdzić cztery z sześciu wymienionych kryteriów: obustronna i symetryczna lokalizacja, wpływ na codzienną aktywność, więcej niż 1 epizod w tygodniu, początek przed 25. rokiem życia, dodatni wywiad rodzinny, brak objawów podczas snu [8] (table 1).

Hiperhydroza pierwotna w większości przypadków obejmuje ograniczony obszar skóry. Najczęściej dotyczy rąk, stóp, pach oraz twarzy. Zwykle lokalizuje się jednocześnie w kilku obszarach anatomicznych [9]. Częstość występowania hiperhydrozy pierwotnej różni się w zależności od regionu świata. W badaniach przeprowadzonych w Stanach Zjednoczonych występuje u 2,8-4,8\%, Szwecji 5,5\%, Niemczech 4,6\%, Japonii 12,8\%, Kanadzie (Vancouver) 12,3\%, Chinach (Szanghaju) 14,5\% osób w populacji [10-14].

\section{Hiperhydroza wtórna}

Hiperhydroza wtórna współistnieje z innymi chorobami lub jest spowodowana przyjmowaniem leków. Może pojawić się między innymi w przebiegu nadczynności tarczycy, cukrzycy, otyłości, gruźlicy, zapalenia wsierdzia, choroby Parkinsona, guzów chromochłonnych oraz chłoniaków Hodgkina. Wśród przyczyn nadpotliwości wymieniane są również leki, takie jak neuroleptyki, leki przeciwdepresyjne, leki hipoglikemizujące, tryptany, opioidy, antybiotyki (ciprofloksacyna), leki przeciwwirusowe (acyklowir), leki przeciwwymiotne, przeciwgorączkowe, niesteroidowe leki przeciwzapalne, substancje o działaniu adrenergicznym oraz cholinergicznym [7]. W stanie fizjologii hiperhydroza wtórna często występuje w okresie ciąży, menopauzy oraz podczas ekspozycji na wysokie temperatury. W jej przebiegu nadpotliwość zwykle dotyczy całego ciała, przybierając postać uogólnioną [5].

Hiperhydroza może również towarzyszyć rzadkim zespołom chorobowym, takim jak zespół Frey, zespół Rileya-Daya, zespół paznokieć-rzepka [15-17]. 
Table I. Diagnostic criteria of primary hyperhidrosis according to the Canadian Hyperhidrosis Advisory Committee [8]

Tabela I. Kryteria diagnostyczne hiperhydrozy pierwotnej wg Canadian Hyperhidrosis Advisory Committee [8]

\begin{tabular}{l} 
Persistence of symptoms of hyperhidrosis for at least \\
6 months and presence of $\geq 4$ criteria/Utrzymywanie się \\
objawów nadpotliwości przez co najmniej 6 miesięcy \\
oraz spełnienie $\geq 4$ kryteriów \\
Bilaterally symmetric sweating/Obustronne, symetryczne \\
pocenie \\
\hline Impairment of daily activities/Ograniczenie codziennej aktywności \\
\hline More than I episode per week/Więcej niż I epizod w tygodniu \\
\hline Age at onset $<25$ years/Początek przed 25 . rokiem życia \\
\hline Positive family history/Dodatni wywiad rodzinny \\
\hline Absence of symptoms during sleep/Brak objawów podczas snu
\end{tabular}

Depending on body location, excessive sweating can be classified as generalised hyperhidrosis, affecting practically the entire body, and focal hyperhidrosis, localised to certain areas, most commonly the armpits, feet, hands or face (tables 2, 3).

\section{DIAGNOSTIC WORK-UP}

The diagnostic work-up for hyperhidrosis is crucially dependent on the patient's medical history and physical examination, as well as results of laboratory tests performed to rule out secondary hyperhidrosis. This is because excessive sweating may also be the first sign suggesting the diagnosis of endocrine disorders, cardiovascular diseases, and even cancer. Patients reporting excessive night sweats should be evaluated to rule out tuberculosis and haematopoietic proliferative disorders. In such cases, priority should be given to the treatment of the underlying disease. The primary origin of hyperhidrosis can be determined by the exclusion of other causes (comorbidities, drugs, stress). Primary hyperhidrosis usually affects people under 30 years of age, and in 35-56\% of cases it is characterised by familial occurrence [1]. Excessive perspiration in a given area of the body can be evaluated by performing the Minor test [18]. The test involves the application of an aqueous solution of iodine and starch to the location of reported excessive sweating (in the axillary regions, on the hands and feet). In response to sweat, the tested skin area changes colour to dark blue. During routine medical visits, photographic documentation is recommended, so that it is possible to compare the severity of the complaint over time. Other available methods for the objective assessment of hyperhidrosis - more challenging to perform in clinical practice - include gravimetry, dynamic sudometry, thermoregulatory sweating test, and skin conductance measurement [7]. Subjective evaluation of the severity of hyperhidrosis may be performed with the use of Hyperhidrosis Dis-
Table 2. Causes of secondary generalised hyperhidrosis [5]

Tabela 2. Przyczyny uogólnionej wtórnej hiperhydrozy [5]

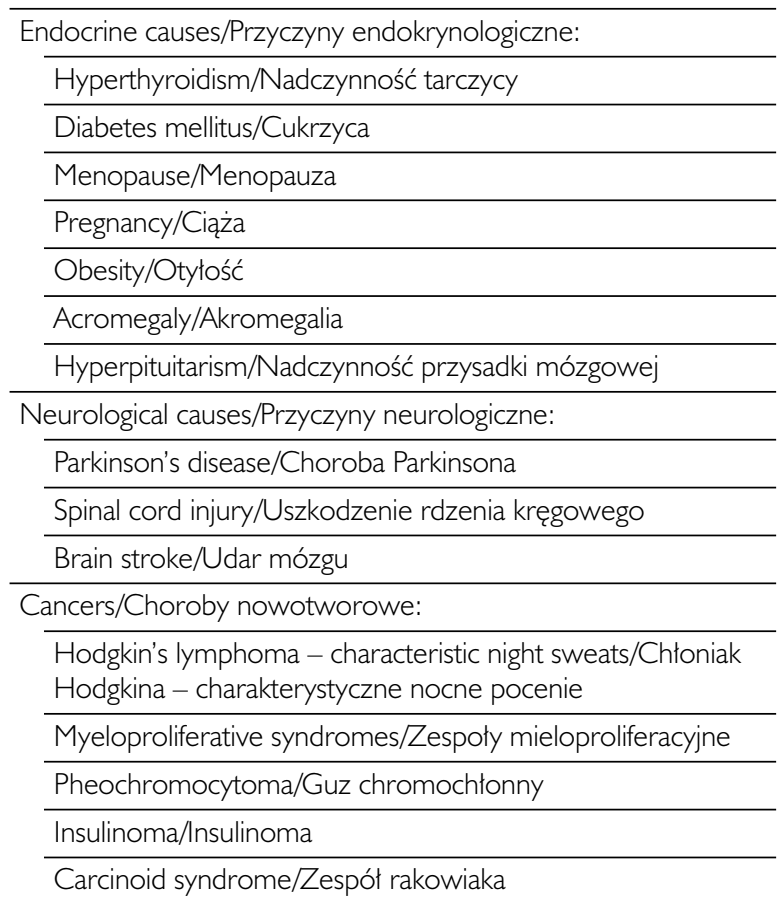

Acute bacterial and viral infections/Ostre infekcje bakteryjne oraz wirusowe

Tuberculosis - characteristic night sweats/Gruźlica charakterystyczne nocne pocenie

\section{Brucellosis/Bruceloza}

Malaria/Malaria

Myocardial infarction/Zawał serca

ShockNstrząs

\section{Drugs/Leki:}

neuroleptics, antidepressants, hypoglycaemics, triptans, opioids, antibiotics (ciprofloxacin), antivirals (acyclovir), antiemetics, antipyretics, NSAIDs, and drugs with adrenergic and cholinergic actions/neuroleptyki, leki przeciwdepresyjne, leki hipoglikemizujące, tryptany, opioidy, antybiotyki (ciprofloksacyna), leki przeciwwirusowe (acyklowir), leki przeciwwymiotne, preparaty przeciwgorączkowe, niesteroidowe leki przeciwzapalne, substancje o działaniu adrenergicznym oraz cholinergicznym

Intoxication and withdrawal symptoms/Zatrucia i zespoły abstynencyjne:

alcohol, cocaine, heroin/alkohol, kokaina, heroina

Table 3. Causes of focal hyperhidrosis $[5,15]$

Tabela 3. Przyczyny ograniczonej hiperhydrozy [5, I5]

Primary idiopathic hyperhidrosis/Pierwotna idiopatyczna hiperhydroza

Frey's syndrome/Zespół Frey

Peripheral neuropathies/Neuropatie obwodowe

Ross' syndrome/Zespół Rossa

Localised unilateral hyperhidrosis (LUH)/Zlokalizowana

jednostronna hiperhydroza (LUH) 
ease Severity Scale (HDSS). It has been demonstrated that a 1-point decrease in the HDSS score correlates with a $50 \%$ reduction, and a 2 -point decrease with an $80 \%$ reduction in the production of sweat measured by gravimetry [19]. The impact of excessive sweating on patients' quality of life can also be assessed by means of questionnaires including The Hyperhidrosis Impact Questionnaire, Dermatology Life Quality Index, and The Medical Outcomes Trust Short Form 12 Health Survey [7]. Individuals with hyperhidrosis have been shown to have a higher prevalence of depression and anxiety disorders. Furthermore, excessive sweating promotes bacterial, viral and fungal infections, and may lead to dyshidrotic eczema. In addition, it may cause psychological discomfort associated with the production of an unpleasant odour, and a tendency to adopt an unnatural posture in an attempt to hide hyperhidrosis-affected areas [7].

\section{TREATMENT OF PRIMARY HYPERHIDROSIS}

The first-line treatment of hyperhidrosis is based on topical agents which act by mechanically blocking sweat pores. Products containing aluminium salts in the form of creams, lotions and powders are recommended [19]. The application results in the formation of a "plug" of polymeric hydroxide gel, which is gradually removed as the stratum corneum exfoliates. Unfortunately, skin irritation is a widely reported adverse reaction. Topical agents should be applied to washed and thoroughly dried skin in the evening, initially every day or every other day, followed by 1-3 times a week to maintain the therapeutic effect.

In recent years, mostly in the popular scientific literature, there have been reports indicating a possible relationship between the use of antiperspirants and an elevated risk of developing breast cancer. Publications have highlighted the fact that excessive exposure to aluminium may cause genome instability in mammary gland epithelial cells, induce abnormal proliferation, and contribute to an increase in migration and invasion of cancer cells. In addition, aluminium (being a metalloestrogen) may produce an oestrogen-like effect, which is claimed to be implicated in the development of breast cancer [20]. However, the results of two epidemiological studies have failed to show a positive association between the use of antiperspirants and an increased risk of breast cancer [21, 22]. In contrast, one study conducted on a group of 437 women with a history of breast cancer has found that the diagnosis of cancer was made at a younger age in women who started using deodorants or antiperspirants earlier, used them more often, and performed axillary depilation. The authors of the study hypothesised that the observed correlation might be
Inny podział uwzględnia lokalizację i wyróżnia hiperhydrozę uogólnioną, obejmującą praktycznie całą skórę, oraz ograniczoną, dotyczącą w szczególności pewnych obszarów, najczęściej pach, stóp, rąk lub twarzy (tab. 2, 3).

\section{DIAGNOSTYKA}

W procesie diagnozowania nadmiernej potliwości kluczowe znaczenie mają badania podmiotowe i przedmiotowe oraz badania laboratoryjne wykonane w celu wykluczenia hiperhydrozy wtórnej. Nadpotliwość może być pierwszym objawem umożliwiającym rozpoznanie zaburzeń endokrynologicznych, chorób układu sercowo-naczyniowego, a nawet nowotworów. U chorych zgłaszających nadmierne pocenie w nocy należy wykluczyć gruźlicę oraz choroby rozrostowe układu krwiotwórczego. W takich przypadkach priorytetem jest leczenie choroby podstawowej. Pierwotny charakter hiperhydrozy rozpoznawany jest po wykluczeniu innych przyczyn (choroby współistniejące, leki, stres). Postać ta dotyczy zwykle osób przed 30. rokiem życia i w 35-56\% przypadków charakteryzuje się rodzinnym występowaniem [1]. W celu potwierdzenia nadmiernej ilości wydzielanego potu w danym obszarze ciała zaleca się wykonanie próby Minora [18]. Polega ona na aplikacji wodnego roztworu jodyny i skrobi w miejscu zgłaszanego nadmiernego wydzielania potu (okolica dołów pachowych, dłoni, stóp). Badany obszar skóry zabarwia się na granatowo. Podczas rutynowych wizyt wskazane jest wykonanie fotodokumentacji w celu porównywania stopnia nasilenia dolegliwości w czasie. Innymi, trudniejszymi do zastosowania w praktyce klinicznej metodami obiektywnej oceny hiperhydrozy są: grawimetria, dynamiczna sudometria, termoregulacyjny test pocenia i pomiar przewodnictwa skóry [7]. Do subiektywnej oceny nasilenia hiperhydrozy wykorzystuje się czterostopniową skalę nasilenia hiperhydrozy - Hyperhidrosis Disease Severity Scale (HDSS). Zbadano, że zmniejszenie o 1 pkt w skali HDSS koreluje z 50-procentową, a o 2 pkt z 80-procentową redukcją wydzielania potu zmierzoną za pomocą grawimetrii [19]. Wpływ nadmiernej potliwości na jakość życia pacjentów można również oceniać za pomocą kwestionariuszy: The Hyperhydrosis Impact Questionnaire, Dermatology Life Quality Index oraz The Medical Outcomes Trust Short Form 12 Health Survey [7]. Zbadano, że u osób z hiperhydrozą częściej niż u osób bez tego objawu występują depresja oraz zaburzenia lękowe. Ponadto nadmierne wydzielanie potu sprzyja infekcjom bakteryjnym, wirusowym i grzybiczym, może prowadzić do powstania wyprysku potnicowego, powodować dyskomfort psychiczny związany z wydzielaniem przykrego zapachu i tendencję do przyj- 
attributable to an increased absorption of aluminium salts due to the depilation-induced disruption of the epidermal barrier [23]. Therefore, determining a link between antiperspirants and the risk of breast cancer requires further research.

Similar suspicions raised with regard to Alzheimer's disease have not been confirmed. Also, early animal research suggested that aluminium exposure might have a contributory effect on neurofibrillary degeneration, but no such association was found in later studies. Currently, Alzheimer's experts believe that the link between daily exposure to aluminium (for example in antiperspirants) and Alzheimer's disease is questionable [24].

Glycopyrrolate in the form of $2 \%$ cream applied twice a day is recommended for the treatment of facial hyperhidrosis and gustatory sweating. In 2018, the U.S. Food and Drug Administration also approved topical wipes containing $2.4 \%$ solution of glycopyrrolate for the treatment of underarm excessive sweating in patients from 9 years of age. Studies conducted to date have demonstrated the safety of topically applied glycopyrrolate. Reported adverse reactions - manifested as dry skin and mucous membranes, headaches, blurred vision, problems with bowel movement and urination, observed in 2 to $25 \%$ of users, were mild to moderate in severity [25].

A common ingredient of body deodorants is alum, a natural mineral used since ancient times. Alum is claimed to have antibacterial and astringent properties, and constrict the sweat pores. One study explored the efficacy and safety of ammonium alum applied to the skin of the face in a group of 23 patients with Frey's syndrome. A decrease in excessive sweat production without secondary skin irritation was observed [26].

The systemic treatment for hyperhidrosis is based on anticholinergic drugs, mainly glycopyrrolate and oxybutynin. However, adverse reactions including dry mouth and conjunctiva, gastrointestinal disorders, difficulty passing urine and tachycardia are among factors limiting their prolonged use. Oxybutynin is a competitive antagonist of muscarinic acetylcholine receptors M1, M2, M3, M4 and M5, approved for the treatment of urinary incontinence. It is also used for the therapy of hyperhidrosis, particularly in cases where the condition affects multiple areas of the body and topical therapy is unsuccessful, at doses of 2.5 to $5 \mathrm{mg}$ twice a day. Studies show that it brings improvement in terms of symptom relief in approximately $70-80 \%$ of patients. The lowest effective dose is typically indicated, so that the risk of adverse drug reactions is low [27]. Researchers also point out that the dose of oxybutynin can be reduced during the winter months when the problem of excessive sweat- mowania nienaturalnej postawy ciała w celu ukrycia miejsc objętych nadpotliwością [7].

\section{LECZENIE HIPERHYDROZY PIERWOTNEJ}

Preparatami pierwszego wyboru w terapii nadpotliwości są preparaty miejscowe, których działanie opiera się na mechanicznym blokowaniu ujść gruczołów potowych. Zalecane są produkty zawierające sole glinu w formie kremów, płynów i zasypek [19]. W wyniku aplikacji tworzy się czop z polimerycznego żelu wodorotlenkowego, usuwany wraz ze złuszczaniem się warstwy rogowej naskórka. Niestety często zgłaszanym objawem niepożądanym jest podrażnienie skóry. Preparaty należy stosować wieczorem, na umytą i dokładnie osuszoną skórę, początkowo codziennie lub co drugi dzień, a następnie w celu podtrzymania efektu terapeutycznego 1-3 razy w tygodniu.

Ostatnio, zwłaszcza w literaturze popularnonaukowej, pojawiły się doniesienia wskazujące na możliwość istnienia związku między stosowaniem antyperspirantów a zwiększonym ryzykiem rozwoju nowotworu sutka. W piśmiennictwie zwraca się uwagę, że nadmierna ekspozycja na glin może wywoływać niestabilność genomu w komórkach nabłonka gruczołów sutkowych, powodować nieprawidłową proliferację, jak również przyczyniać się do zwiększonej migracji i inwazji komórek nowotworowych. Ponadto glin jako metaloestrogen może mieć działanie podobne do estrogenów, którym przypisywany jest udział $\mathrm{w}$ powstawaniu nowotworów piersi [20]. Wyniki dwóch badań epidemiologicznych nie potwierdzają jednak pozytywnej korelacji między stosowaniem antyperspirantów a zwiększonym ryzykiem raka piersi [21, 22]. W jednej z analiz dotyczącej grupy 437 kobiet $\mathrm{z}$ nowotworem piersi w wywiadzie wykazano, że u pacjentek, które wcześniej rozpoczęły i częściej stosowały dezodoranty lub antyperspiranty oraz przeprowadzały depilację dołów pachowych, diagnozę nowotworu ustalono we wcześniejszym wieku. Autorzy badania rozważają, czy przyczyną obserwowanej korelacji mogłaby być zwiększona absorpcja soli glinu, wzmożona wskutek przerwania bariery naskórkowej depilacją [23]. Dlatego też określenie związku między korzystaniem z antyperspirantów a ryzykiem rozwoju nowotworu sutka wymaga dalszych badań.

Podobne podejrzenia nie potwierdziły się w przypadku choroby Alzheimera. Wczesne badania na zwierzętach sugerowały możliwy wpływ ekspozycji na aluminium na powstawanie zwyrodnień neurowłókienkowych, czego jednak nie potwierdziły późniejsze badania. Aktualnie eksperci zajmujący się chorobą Alzheimera stoją na stanowisku, że związek między 
ing is less pronounced. Oxybutynin is absolutely contraindicated in patients with narrow-angle glaucoma, myasthenia gravis, and gastrointestinal disorders [28]. Glycopyrrolate has the advantage of being unable to cross the blood-brain barrier, which reduces the risk of developing adverse reactions. The drug is administered at a dose of 1-2 mg twice daily [24].

Another drug which may be beneficial in the therapy of hyperhidrosis is propranolol - a non-selective $\beta$-blocker recommended especially in cases when hyperhidrosis is accompanied by anxiety and stress [29].

Focal hyperhidrosis, particularly localised to the hands and feet, can be treated by iontophoresis. The technique involves the introduction of ions into body tissues via direct or pulsed current [30]. Iontophoresis treatments are postulated to produce antiinflammatory, bacteriostatic and anaesthetic action, and have a stimulatory effect on blood flow. This form of electrotherapy is used in the treatment of degenerative and inflammatory diseases of the musculoskeletal system, nerve damage, and local disorders of blood supply to tissues. It may also bring therapeutic benefits in patients with dilated capillaries, sagging skin, scars, rosacea, and acne vulgaris. The mechanism of action of iontophoresis in the therapy of hyperhidrosis has not been thoroughly understood. The clinical benefit is probably due to the blocking of ducts of eccrine sweat glands, inhibition of nerve conduction, and changes in the $\mathrm{pH}$ reducing the activity of the glands [31-33]. Contraindications to iontophoresis include implantable cardiac stimulators, endoprostheses, metal implants located near the site of treatment, cardiac arrhythmia, epilepsy, and pregnancy [34]. The resolution of symptoms is achieved within approximately 1 to 4 weeks of regular treatments. To retain the desired therapeutic response, maintenance therapy applied every few months is usually necessary. Iontophoresis treatments can also be performed in the paediatric population, the main advantage of the procedure being its low invasiveness [35]. Since devices for home use are also available, iontophoresis treatments can be performed systematically. Evidence for the therapeutic efficacy of the technique has been found in the ongoing studies at the Dermatology Department in Lodz.

Another therapeutic option, approved in Poland for the treatment of axillary hyperhidrosis refractory to topical medications, is based on botulinum toxin type A injections [36]. This method is also used as a therapeutic alternative in the management of patients with hyperhidrosis of the hands and feet. A potential adverse reaction of skin injection is transient paralysis of adjacent muscles, which can be particularly troublesome for patients performing precise manual tasks. The literature codziennymi źródłami aluminium (takimi jak antyperspiranty) a chorobą Alzheimera jest wątpliwy [24].

Glikopirolan w postaci $2 \% \mathrm{kremu}$, aplikowany 2 razy dziennie jest rekomendowany do leczenia nadpotliwości twarzy oraz $\mathrm{w}$ poceniu smakowym. W 2018 r. amerykańska Agencja Żywności i Leków dopuściła do leczenia nadpotliwości pach u osób od 9. roku życia chusteczki nawilżone $2,4 \%$ roztworem glikopirolanu. W dotychczas przeprowadzonych badaniach wykazano bezpieczeństwo miejscowej aplikacji glikopirolanu, a działania niepożądane, takie jak suchość skóry i błon śluzowych, ból głowy, nieostre widzenie, problemy z wypróżnianiem i oddawaniem moczu, zgłaszane u 2-25\% użytkowników miały nasilenie łagodne do umiarkowanego [25].

Powszechnym składnikiem dezodorantów jest również ałun - naturalny minerał stosowany już w starożytności. Przypisuje mu się działanie antybakteryjne, ściągające oraz zwężające ujścia gruczołów potowych. W jednym z badań testowano skuteczność i bezpieczeństwo ałunu amonowego aplikowanego na skórę twarzy u 23 osób z zespołem Frey. Opisano poprawę $\mathrm{w}$ zakresie nadmiernego wydzielania potu bez towarzyszącego podrażnienia skóry [26].

W terapii ogólnej hiperhydrozy stosowane są leki antycholinergiczne, zwłaszcza glikopirolan oraz oksybutynina. Jednak działania niepożądane, takie jak suchość jamy ustnej, spojówek, zaburzenia czynności przewodu pokarmowego, trudności w oddawaniu moczu, tachykardia, często ograniczają ich przewlekłe przyjmowanie. Oksybutynina jest kompetytywnym antagonistą acetylocholinowych receptorów muskarynowych M1, M2, M3, M4 i M5, zarejestrowaną $\mathrm{w}$ leczeniu nietrzymania moczu. Stosowana jest również w nadpotliwości, zwłaszcza dotyczącej wielu obszarów ciała, przy niezadowalających efektach terapii miejscowej, w dawkach 2,5-5 mg 2 razy dziennie. Wyniki badań wykazują poprawę w zakresie odczuwanych dolegliwości u ok. 70-80\% pacjentów. Zwykle zalecana jest najmniejsza skuteczna dawka leku, aby ryzyko wystąpienia działań niepożądanych było niewielkie [27]. Badacze zwracają uwage na możliwość zmniejszenia dawki oksybutyniny w czasie miesięcy zimowych, gdy problem nadpotliwości jest mniej nasilony. Oksybutynina jest bezwzględnie przeciwwskazana u osób z jaskrą z wąskim kątem przesączania, miastenią oraz zaburzeniami układu pokarmowego [28]. Zaletą glikopirolanu jest fakt, że substancja ta nie przekracza bariery krew-mózg, co zmniejsza ryzyko rozwoju działań niepożądanych. Lek podaje się 2 razy dziennie $\mathrm{w}$ dawce 1-2 mg [24].

Innym lekiem, który może być pomocny w terapii hiperhydrozy, jest propranolol - nieselektywny 
also contains reports on the treatment with botulinum toxin type B $[37,38]$. In Poland, the method is approved solely for the treatment of cervical dystonia in adult patients. The mechanism of action of botulinum toxin involves inhibition of the release of acetylcholine from presynaptic vesicles, and thus suppression of cholinergic transmission in the motor end plate of skeletal muscles, as well as autonomic fibres innervating the sweat, lacrimal, and salivary glands or smooth muscles. Botulinum toxin type A has a wide range of applications in neurology, urology (in the treatment of overactive bladder), and aesthetic medicine [39, 40]. Contraindications to using botulinum toxin type A include myasthenia gravis, Lambert-Eaton myasthenic syndrome, active infections within the application area, and known hypersensitivity to any ingredient of the product. Particular caution should be exercised in patients taking oral anticoagulants on account of an increased risk of subcutaneous haematomas at injection sites. An advantage of the method is that it rapidly produces a satisfactory therapeutic response persisting on average for 6 to 9 months [41].

Other reported methods for the treatment of hyperhidrosis include laser therapy, microneedle radiofrequency, and ultrasound- and microwave-based technologies which are recommended in particular for the relief of hyperhidrosis limited to the axillary area [24].

If symptoms associated with hyperhidrosis are very severe, and less invasive methods of treatment fail to provide adequate relief, a surgical procedure can be considered, with options including sympathectomy, sympathetomy, topical sweat gland removal or subcutaneous axillary curettage using liposuction devices (liposuction-curettage).

The most widely used surgical method is sympathectomy, which is currently performed mainly endoscopically. The aim of the procedure is transection of the sympathetic nerve trunk, so that the blood vessels in the denervated area of the body become dilated, and sweat production decreases. Sympathectomy has also found application in the treatment of Raynaud's disease and Buerger's disease involving the upper limbs. The efficacy of hyperhidrosis treatment with this method is very high, though some patients may develop compensatory hyperhidrosis. Other reported complications include surgical site bleeding, pneumothorax or subcutaneous oedema, Horner's syndrome, sympathetic neuralgia, phantom sweating, and dry skin [42].

\section{CONCLUSIONS}

Hyperhidrosis is a condition subjectively perceived as embarrassing and socially disabling, and $\beta$-adrenolityk, rekomendowany zwłaszcza w nadpotliwości, której towarzyszy lęk i stres [29].

W leczeniu zlokalizowanej hiperhydrozy, szczególnie dotyczącej rąk i stóp, zastosowanie terapeutyczne znalazły zabiegi jontoforezy. Jontoforeza polega na wprowadzaniu do tkanek jonów za pomocą prądu stałego lub pulsującego [30]. Zabiegom jontoforezy przypisywane jest działanie przeciwzapalne, bakteriostatyczne, znieczulające, pobudzające krążenie w naczyniach krwionośnych. Ta forma elektroterapii jest stosowana w zwyrodnieniowych i zapalnych schorzeniach narządów ruchu, uszkodzeniach nerwów, zaburzeniach miejscowego ukrwienia tkanek. Może okazać się pomocna przy rozszerzonych naczyniach włosowatych, zwiotczeniu skóry, bliznach, trądziku różowatym oraz trądziku pospolitym. Mechanizm działania jontoforezy w leczeniu nadpotliwości nie został dokładnie poznany. Korzystny efekt kliniczny uzyskiwany jest prawdopodobnie poprzez zamknięcie przewodów wyprowadzających gruczołów ekrynowych, hamowanie przewodnictwa nerwowego i zmianę $\mathrm{pH}$ ograniczającą aktywność gruczołów [31-33]. Przeciwwskazaniami do jontoforezy są: wszczepione urządzenia stymulujące pracę serca, endoprotezy, metalowe implanty zlokalizowane w pobliżu miejsca leczenia, arytmia serca, padaczka oraz ciąża [34]. Ustąpienie dolegliwości uzyskuje się po ok. 1-4 tygodniach regularnych zabiegów. Dla utrzymania pożądanych efektów zwykle konieczna jest terapia podtrzymująca, stosowana co kilka miesięcy. Zabiegi jontoforezy mogą być stosowane również w populacji pediatrycznej, a ich zaletą jest mała inwazyjność [35]. Dostępne są również urządzenia przeznaczone do stosowania domowego, co sprzyja systematycznemu poddawaniu się zabiegom jontoforezy. Dobre efekty terapii potwierdzają dotychczasowe doświadczenia łódzkiej Kliniki Dermatologii (badania w toku).

Inną możliwością terapeutyczną, zarejestrowaną w Polsce do leczenia opornej na preparaty miejscowe nadmiernej potliwości pach, są iniekcje toksyny botulinowej typu A [36]. Metoda ta stosowana jest również alternatywnie $\mathrm{w}$ hiperhydrozie rąk i stóp. Objawem niepożądanym wstrzyknięcia do skóry jest ryzyko przejściowego porażenia okolicznych mięśni, co może być szczególnie uciążliwe dla osób wykonujących precyzyjne prace manualne. $\mathrm{W}$ piśmiennictwie dostępne są dane dotyczące stosowania również toksyny botulinowej typu B $[37,38]$. W Polsce ma ona rejestrację jedynie $\mathrm{w}$ leczeniu dystonii szyjnej u osób dorosłych. Mechanizm działania toksyny botulinowej polega na hamowaniu wydzielania acetylocholiny z pęcherzyków presynaptycznych, a także blokowaniu przekaźnictwa cholinergicznego w płytce motorycznej mięśni szkieletowych 
patients often attempt to treat it by themselves. The disorder can significantly impair the quality of daily life, and even cause affected individuals to withdraw from social life. The first step in the diagnostic workup for hyperhidrosis is to rule out secondary causes of the condition, following which an optimal therapeutic modality, adjusted to the type of the condition, severity of symptoms and patient expectations, can be initiated. The therapy should preferably begin with topical agents, and if no satisfactory effect is achieved, systemic therapy or outpatient procedures should be introduced. The treatment of last resort is surgical management.

\section{CONFLICT OF INTEREST}

The authors declare no conflict of interest. oraz we włóknach autonomicznych unerwiających gruczoły potowe, łzowe, ślinowe lub mięśnie gładkie. Toksyna botulinowa typu A jest powszechnie wykorzystywana w neurologii, urologii (w leczeniu nadreaktywności pęcherza moczowego) oraz medycynie estetycznej [39, 40]. Przeciwwskazaniami do jej stosowania są: miastenia, zespół Lamberta-Eatona, czynne zakażenia w obszarze aplikacji oraz znana nadwrażliwość na którykolwiek składnik preparatu. U osób przyjmujących doustne leki przeciwkrzepliwe należy zachować szczególną ostrożność, ponieważ zwiększa się ryzyko wystąpienia krwiaków podskórnych w miejscach iniekcji. Zaletą tej metody jest szybki, satysfakcjonujący, trwający średnio 69 miesięcy efekt terapeutyczny [41].

Wśród innych metod leczenia hiperhydrozy mają zastosowanie: laseroterapia, radiofrekwencja mikroigłowa, technologie z wykorzystaniem ultradźwięków oraz mikrofal, szczególnie zalecane w nadpotliwości ograniczonej do dołów pachowych [24].

Jeżeli dolegliwości związane z hiperhydrozą są bardzo nasilone, a mniej inwazyjne metody leczenia zawodzą, możliwe jest również poddanie się zabiegowi chirurgicznemu - sympatektomii, sympatetomii, miejscowemu wycięciu gruczołów potowych lub podskórnemu łyżeczkowaniu dołu pachowego z zastosowaniem urządzeń do liposukcji.

Najczęściej stosowaną metodą chirurgiczną jest sympatektomia, obecnie wykonywana głównie techniką endoskopową. Polega ona na przerwaniu ciągłości pnia współczulnego. W efekcie tego zabiegu dochodzi do rozszerzenia naczyń krwionośnych w odnerwionym obszarze ciała oraz zmniejszenia wydzielania potu. Sympatektomia znalazła również zastosowanie w leczeniu choroby Raynauda oraz choroby Buergera obejmującej kończyny górne. Skuteczność leczenia nadpotliwości tą metodą jest bardzo wysoka, jednak u części osób może wystąpić nadpotliwość kompensacyjna. Wśród innych powikłań sympatektomii opisywano wystąpienie krwawienia z miejsca operowanego, odmy opłucnowej lub podskórnej, zespołu Hornera, neuralgii współczulnej, nadpotliwości fantomowej, a także suchości skóry [42].

\section{PODSUMOWANIE}

Nadpotliwość to wstydliwa, często ukrywana dolegliwość, z którą pacjent nierzadko próbuje walczyć samodzielnie. Może znacznie obniżać jakość codziennego funkcjonowania, a nawet prowadzić do wycofania się z życia społecznego. W diagnostyce hiperhydrozy należy pamiętać o wykluczeniu jej wtórnych przyczyn, a następnie zaproponować optymalną formę terapii z uwzględnieniem rodzaju, nasilenia objawów oraz oczekiwań pacjenta. Zalecane jest jednak rozpoczynanie leczenia od preparatów miejscowych, 
w późniejszych etapach leczenie ogólne lub zabiegowe, a w ostateczności metody chirurgiczne.

\section{KONFLIKT INTERESÓW}

Autorzy nie zgłaszają konfliktu interesów.

\section{References}

\section{Piśmiennictwo}

1. Solish N., Bertucci V., Dansereau A., Hong HC., Lynde C., Lupin M., et al.: A comprehensive approach to the recognition, diagnosis, and severity-based treatment of focal hyperhidrosis: recommendations of the Canadian Hyperhidrosis Advisory Committee. Dermatol Surg 2007, 33, 908-923.

2. Adamski Z., Kaszuba A.: Dermatologia dla kosmetologów. Uniwersytet Medyczny im. Karola Marcinkowskiego w Poznaniu, Poznań, 2008.

3. Murota H.: Sweating in systemic abnormalities: uremia and diabetes mellitus. Curr Probl Dermatol 2016, 51, 57-61.

4. Nadlewska A., Ladny J., Wojewódzka-Żelezniakowicz M., Czaban S., Kosierkiewicz W., Szymańska A., et al.: Trucizny definicja, rodzaje, mechanizm działania. Post Nauk Med 2010, 9, 704-708.

5. Haider A., Solish N.: Focal hyperhidrosis: diagnosis and management. CMAJ 2005, 172, 69-75.

6. Hebert A., Glaser D., Ballard A.: Prevalence of primary focal hyperhidrosis (PFHh) among teens 12-17 in US Population. $75^{\text {th }}$ Annual Meeting of the American Academy of Dermatology. Orlando, 2017. Abstract (5192) presented at American Academy of Dermatology March 2017, Late-Breaking Research: Clinical Studies/Pediatric (F072).

7. Nawrocki S., Cha J.: The etiology, diagnosis and management of hyperhidrosis: a comprehensive review. Part I. Etiology and clinical work-up. J Am Acad Dermatol 2019, 81, 657-666.

8. Hornberger J., Grimes K., Naumann M., Glaser D., Lowe N., Naver H., et al.: Multi-specialty working group on the recognition, diagnosis, and treatment of primary focal hyperhidrosis. Recognition, diagnosis, and treatment of primary focal hyperhidrosis. J Am Acad Dermatol 2004, 51, 274-286.

9. Estevan F., Wolosker M., Wolosker N., Puech-Leão P.: Epidemiologic analysis of prevalence of the hyperhidrosis. An Bras Dermatol 2017, 92, 630-634.

10. Strutton D., Kowalski J., Glaser D., Stang P.: US prevalence of hyperhidrosis and impact on individuals with axillary hyperhidrosis: results from a national survey. J Am Acad Dermatol 2004, 51, 241-248.

11. Doolittle J., Walker P., Mills T., Thurston J.: Hyperhidrosis: an update on prevalence and severity in the United States. Arch Dermatol Res 2016, 308, 743-749.

12. Shayesteh A., Janlert U., Brulin C., Boman J., Nylander E.: Prevalence and characteristics of hyperhidrosis in Sweden: a cross-sectional study in the general population. Dermatology 2016, 232, 586-591.

13. Fujimoto T., Kawahara K., Yokozeki H.: Epidemiological study and considerations of primary focal hyperhidrosis in Japan: from questionnaire analysis. J Dermatol 2013, 40, 886-890.

14. Liu Y., Bahar R., Kalia S., Huang R., Phillips A., Su M., et al.: Hyperhidrosis prevalence and demographical characteristics in dermatology outpatients in Shanghai and Vancouver. PLoS One 2016, 11, e0153719.

15. Ohshima Y., Tamada Y.: Classification of systemic and localized sweating disorders. Curr Probl Dermatol 2016, 51, 7-10.

16. Shetty A., Parikh P., Khubchandani R.: Familial dysautonomia (Riley-Day syndrome). Indian J Pediatr 1995, 62, 367-369.

17. Pechman K., Bergfeld W.: Palmar-plantar hyperhidrosis occurring in a kindred with nail-patella syndrome. J Am Acad Dermatol 1980, 3, 627-632.

18. Muller S., Kierland R.: The use of a modified starch-iodine test for investigating local sweating responses to intradermal injection of methacholine. J Invest Dermatol 1959, 32, 126-128.

19. Grabell D., Hebert A.: Current and emerging medical therapies for primary hyperhidrosis. Dermatol Ther 2017, 7, 25-36.

20. Darbre P.: Aluminium and the human breast. Morphologie 2016, 100, 65-74.

21. Mirick D., Davis S., Thomas D.: Antiperspirant use and the risk of breast cancer. J Natl Cancer Inst 2002, 94, 1578-1580.

22. Fakri S., Al-Azzawi A., Al-Tawil N.: Antiperspirant use as a risk factor for breast cancer in Iraq. East Mediterr Health J 2006, $12,478-482$.

23. McGrath K.: An earlier age of breast cancer diagnosis related to more frequent use of antiperspirants/deodorants and underarm shaving. Eur J Cancer Prev 2003, 12, 479-485.

24. Nawrocki S., Cha J.: The etiology, diagnosis and management of hyperhidrosis: a comprehensive review. Part II. Therapeutic options. J Am Acad Dermatol 2019, 81, 669-680.

25. Chabicovsky M., Winkler S., Soeberdt M., Kilic A., Masur C., Abels C.: Pharmacology, toxicology and clinical safety of glycopyrrolate. Toxicol Appl Pharmacol 2019, 370, 154-169.

26. Chueasupparobon N., Rawangban W., Tangjaturonrasme N.: Treatment of Frey's syndrome with topical ammonium alum: first report with twenty-two cases. Clin Otolaryngol 2016, 41, 593-596.

27. Jarrett J., Moss D.: PURLs: oral agent offers relief from generalized hyperhidrosis. J Fam Pract 2017, 66, 392-394.

28. Delort S., Marchi E., Corrêa M.: Oxybutynin as an alternative treatment for hyperhidrosis. An Bras Dermatol 2017, 92, $217-$ 220.

29. Glaser D.: Oral medications. Dermatol Clin 2014, 32, 527-532.

30. Krueger E., Claudino J., Scheeren E., Neves E., Mulinari E., Nohama P.: Iontophoresis: principles and applications. Fisioter Mov 2014, 27, 469-481. 
31. Hill A., Baker G., Jansen G.: Mechanism of action of iontophoresis in the treatment of palmar hyperhidrosis. Cutis 1981, 28, 69-72.

32. Anliker M., Kreyden O.: Tap water iontophoresis. Curr Probl Dermatol 2002, 30, 48-56.

33. Wang L., Hilliges M., Gajecki M., Marcusson J., Johansson O.: No change in skin innervation in patients with palmar hyperhidrosis treated with tap-water iontophoresis. Br J Dermatol 1994, 131, 742-743.

34. Pariser D., Ballard A.: Iontophoresis for palmar and plantar hyperhidrosis. Dermatol Clin 2014, 32, $491-494$.

35. DogrukKacar S., Ozuguz P., Eroglu S., Polat S., Karaca S.: Treatment of primary hyperhidrosis with tap water iontophoresis in paediatric patients: a retrospective analysis. Cutan Ocul Toxicol 2014, 33, 313-316.

36. De Almeida A., Montagner S.: Botulinum toxin for axillary hyperhidrosis. Dermatol Clin 2014, 22, 495-504.

37. Basciani M., Di Rienzo F., Bizzarrini M., Zanchi M., Copetti M., Intiso D.: Efficacy of botulinum toxin type B for the treatment of primary palmar hyperhidrosis: a prospective, open, single-blind, multi-centre study. Arch Dermatol Res 2014, 306, 497-503.

38. Rosell K., Hymnelius K., Swartling C.: Botulinum toxin type A and B improve quality of life in patients with axillary and palmar hyperhidrosis. Acta Derm Venereol 2013, 93, 335-339.

39. Hsieh P., Chiu H., Chen K., Chang C., Chou E.: Botulinum toxin A for the treatment of overactive bladder. Toxins $2016,8,59$.

40. Satriyasa B.: Botulinum toxin A for reducing the appearance of facial wrinkles: a literature review of clinical use and pharmacological aspect. Clin Cosmet Investig Dermatol 2019, 12, 223-228.

41. Doft M., Hardy K., Ascherman J: Treatment of hyperhidrosis with botulinum toxin. Aesthet Surg J 2012, 32, 238-244.

42. Krasna M.: The role of surgical treatment of hyperhidrosis. Mayo Clin Proc 2011, 86, 717-718.

Received: 1.12 .2019

Accepted: 14.05 .2020

Otrzymano: $1.12 .2019 \mathrm{r}$.

Zaakceptowano: $14.05 .2020 \mathrm{r}$. 